\title{
Fragmentos de identidad insular: paisaje y cultura local como herramientas para la planificación turística de Agaete [España] y Alghero [Italia]
}

SELECCIÓN VIII SEMINARIO INTERNACIONAL DE INVESTIGACIÓN EN URBANISMO

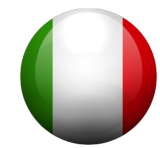

\section{Omar Sosa García}

Arquitecto por la Universidad de Las Palmas de Gran Canaria. Doctorando de la Facoltà di Architettura di Alghero. Alghero [Sassari] Italia. <omar.sosa.garcia@gmail.com>

\section{Resumen}

Algunas ciudades históricas costeras, con cierto potencial de desarrollo turístico y arraigadas tradiciones culturales, necesitan una planificación adecuada para afrontar dicho desarrollo. La sobreexplotación de la franja costera impulsa el deterioro de los valores que la hacen diferentes de otros territorios, razón básica de su posible atractivo turístico. Así, bajo la consideración de que la cultura local y el paisaje están intrínsecamente unidos, influencian el evolución de dichas ciudades y territorios y pueden ser la base de un desarrollo turístico ambiental y socialmente sostenible, se plantea el análisis, en los casos de Agaete y Alghero, de toda forma de expresión de la tradición histórica local para componer la imagen contemporánea de su cultura, donde el paisaje sea el elemento articulador de los espacios en los que esta cultura se desarrolla, permitiendo la comprensión de su ordenación física a través del territorio y su posterior puesta en valor.

\section{Palabras clave}

Turismo sostenible. Planificación de la costa. Cultura local. Paisaje.

\section{Fragments of insular identity: landscape and local culture as tools for the tourism planning of Agaete [Spain] and Alghero [Italy]}

\begin{abstract}
Some coastal historic cities with certain potential of tourism development and strong cultural traditions need a proper planning able to tackle such development. Overexploitation of the coastal strip drives the deterioration of the elements that make it different from other territories, basic reason for its possible tourist attraction. Local culture and landscape are inextricably linked, influence cities and territories development and can be the basis of an environmentally and socially sustainable tourism development. So, with Agaete and Alghero as cases of study, analysis of all forms of expression of the local, historical tradition will set the contemporary image of their culture, where landscapes articulate spaces in which this culture is developed, allowing to understand its territorial structure and its subsequent revaluation.
\end{abstract}

\section{Keywords}

Sustainable tourism. Coast planning. Local culture. Landscape. 


\section{La Costa como lienzo del Turismo}

Islas enmarcadas en un mar o liberadas en el océano, territorios dibujados por la costa, ciudades con olor a sal, playas de todas las texturas bañadas por el mismo líquido elemento. Cuatro escalas que hablan de la relación entre la tierra y el mar, imagen que ocupa una amplia superficie de la oferta turística que aparece en webs y folletos de touroperadores de todo el mundo. Esta imagen - siempre intencionada- suele estimular la imaginación de los turistas con idílicos destinos, donde la playa y el resort constituyen la oferta preponderante. Parece normal que las expectativas se centren, pues, en lo que se oferta (porque es en definitiva lo que se paga), y no en lo fundamental: la población local y su profunda relación con un territorio que ha construido, vivido y transformado. Pero existe una tendencia creciente a abandonar la impostura de los productos turísticos habituales para afrontar una creciente voluntad, tanto del visitado como del visitante, de lo real. La visita, el conocimiento, la mezcla homogénea del turista con ese territorio podría ser el objeto último de este turismo sostenible, que comporta, además, los básicos valores de sostenibilidad, tanto económicos, como sociales y ambientales. El mayor de los retos está en la propia ordenación del territorio, en cómo éste se presenta al visitante y en cómo permite ser vivido por el hospedante.

En los años 50, pasados los efectos de la Segunda Guerra Mundial y derivado de una serie de cambios sociales y económicos, el turismo renace y adquiere un desarrollo imparable. La eliminación de las sanciones de la ONU, los acuerdos con EEUU e incluso la creación del Ministerio de Información y Turismo, hacen de España uno de los países con mayor impulso económico del sector, con la costa como piedra angular de su planificación. Un escenario similar a todos los niveles producía también en Italia el inicio de su desarrollo turístico, con alemanes y austriacos liderando la búsqueda de sol y playa. Este crecimiento explosivo, en ausencia de una planificación capaz, produjo, durante los años sucesivos, un desarrollo urbano regido en alto grado por su dimensión económica, en detrimento de valores como la cultura local y el paisaje, necesarios para la propia conservación de este nuevo y preciado recurso económico.

Ha quedado claro, a través de innumerables ejemplos de la franja litoral mediterránea española e italiana, o en el propio caso de Canarias, que el crecimiento de la oferta hotelera y de recreación ligada al turismo ha tenido un fuerte impacto en la costa. Las áreas de mayor presión urbanística se han desarrollado en territorios que no poseían una estructura urbana y social previa estrechamente ligada a los mismos. En la actualidad, con un turismo más maduro, que empieza a apostar por el verdadero conocimiento de nuevas culturas, asistimos a la transformación de unos territorios que poseen una fuerte dimensión cultural, que necesita ser ofrecida y protegida por igual.

Los casos de estudio de Agaete y Alghero, en Gran Canaria y Cerdeña respectivamente, permiten, con sus diferencias de afluencia turística, estacionalidad, cultura, paisaje, posición geográfica, etc., y dentro de un marco común de insuficiente investigación y planificación turística, establecer las bases comparativas para llegar a conclusiones a niveles tanto generales, en relación a realidades insulares, como específicas. Así, sobre las hipótesis de que ambos territorios tienen la capacidad y necesitan extender el polo de atracción turístico desde la playa hacia otros elementos culturales y paisajísticos, que existe una clara trascendencia del espacio agrario en la cultura local y el desarrollo territorial, y que poseen una rica cultura local sobre la que basar una planificación turística capaz de subrayar la identidad de su territorio, se articula la puesta en valor de los elementos que componen la herencia cultural y el paisaje de estos territorios, como eje central de la planificación turística, a través de un análisis que permita reconsiderar la relación entre los mismos y la propia población local.

\subsection{Planificación en la costa insular}

En España, ilustrando cómo se ha podido producir la degradación del litoral, la evolución de las diferentes versiones de la Ley de Costas han dibujado la relación entre el espacio público litoral y el suelo susceptible de pertenecer y ser gestionado por particulares. En 1963, con la ausencia de una legislación de costas y en un contexto de expansión económica, agotamiento de la dictadura franquista y apertura del país al turismo, se propone una ley para el impulso y creación de centros turísticos que propicia el desarrollo de la primera Ley de Costas, que llegará en 1969. 
Legitimada sobre un futuro y potente desarrollo económico, su aplicación provoca la privatización del litoral para el turismo, con la consiguiente degradación urbanística. Más adelante, la Constitución de 1978 intenta revertir esta privatización, introduciendo el concepto de litoral como dominio público "por naturaleza", lo que unido a diversos informes desfavorables por parte de varios organismos internacionales, propicia la creación de una nueva Ley de Costas en 1988. Ésta se plantea como una radical oposición a la anterior ley pero tuvo como efecto involuntario que los ayuntamientos de municipios costeros se apresuraran a la aprobación de planes que clasificaran la mayor parte posible del suelo cercano al mar para evitar la pérdida de aprovechamientos urbanísticos, produciendo que la nueva línea de protección costera en suelo rústico, que pasa de 20 a 100 metros, resulte ineficaz una vez aprobada la Ley. En cualquier caso, como aspecto positivo, pretende la conservación de espacios naturales y la recuperación del uso público de los terrenos ocupados.

Más adelante, la sostenibilidad de los recursos naturales y públicos del litoral se establece como la base de la nueva Ley de protección y uso sostenible del litoral y de modificación de la Ley de Costas, aprobada en 2013. La administración pública compone finalmente un documento que regula el litoral como bien común, describiéndolo como "un ecosistema sensible y vulnerable que precisa protección", reglamenta el uso de las playas e introduce medidas para el control administrativo ambiental. Esto tendrá como consecuencia una visión de la costa a largo plazo, componiendo una serie de medidas que permitan garantizar un desarrollo futuro sólo tendente a su mejora ambiental y a una adecuada relación con los territorios colindantes. Considerando que la franja perimetral de un territorio insular se compone de costa en su totalidad, resulta evidente que esta ley, la Ley del Suelo y Rehabilitación Urbana y las Leyes de Ordenación del Territorio de Canarias y de Espacios Naturales de Canarias (LOTENC), deben tender a una máxima integración entre los territorios costero, urbano y rural.

Las intervenciones sobre la costa turística han comportado mayores beneficios económicos para la administración en reducidos espacios de tiempo que otros casos de planeamiento en la costa, resultando respectivamente en la creación de nuevos núcleos o en la expansión de antiguas áreas urbanas de origen no turístico. Este último caso es el de mayor preocupación, dada la fragilidad de la relación entre un territorio, la sociedad que lo habita y su cultura. La creación de nuevos paisajes urbanos a través de edificaciones ajenas al contexto arquitectónico preexistente, la privatización -en todas sus evidentes y sutiles formas - de los espacios libres, procesos de gentrificación de diversa naturaleza, ausencia en muchos casos de verdadera relación local-visitante, sobreexplotación de las playas, pérdida de identidad y disminución de la autoestima de la población local, falta de relación con el espacio costero, etc., componen gran parte de la problemática que incide en esa triada territorio-sociedad-cultura.

\subsection{Influencia sobre el territorio y la sociedad local}

Parece imposible que después de la catástrofe que supone el haber alterado casi todo el litoral español, borrando las acusadas características que diferenciaban cada lugar por la completa falta de adecuación, introduciendo gratuitamente una fría estandarización internacional, no hayamos podido todavía aprender la lección, para rectificar y salvar lo que nos queda (Manrique, 1988, pp. 87-88).

César Manrique, artista lanzaroteño, explica con estas palabras, en su libro "Escrito en el fuego", cómo la inercia de un inapropiado desarrollo turístico esquilma las cualidades que hacen único a un territorio, donde el paisaje insular, la arquitectura vernácula (Figura 1) y el propio habitante constituyen su mayor preocupación.

Los cambios que produce el turismo sobre una población insular pueden ser muy profundos, aunque hay que considerar los aspectos positivos y negativos, tal y como lo hace su propia población (Macleod, 2004).Su identidad ha quedado, en el caso de un estudio en la isla canaria de La Gomera, dividida entre ideales anteriores y posteriores a la llegada del turismo. Una mayor apertura y mezcla con otras culturas diluye la suya propia, que será más tendente una visión globalizadora, donde los aspectos económicos pueden primar sobre otros. La escenificación de un supuesto folclore local, la perpetuación de una cultura simulada con el fin de satisfacer las creencias extranjeras de lo que se supone que debe ser esa cultura insular, la creación de entornos urbanos 
instalados en la imaginería del colectivo turístico, tiene amplia representación en varios destinos turísticos. Estas falsas representaciones de las identidades locales tienen como característica común un lento pero implacable desarrollo, que necesitará de pocas generaciones para alcanzar el olvido de lo que una vez fue real.

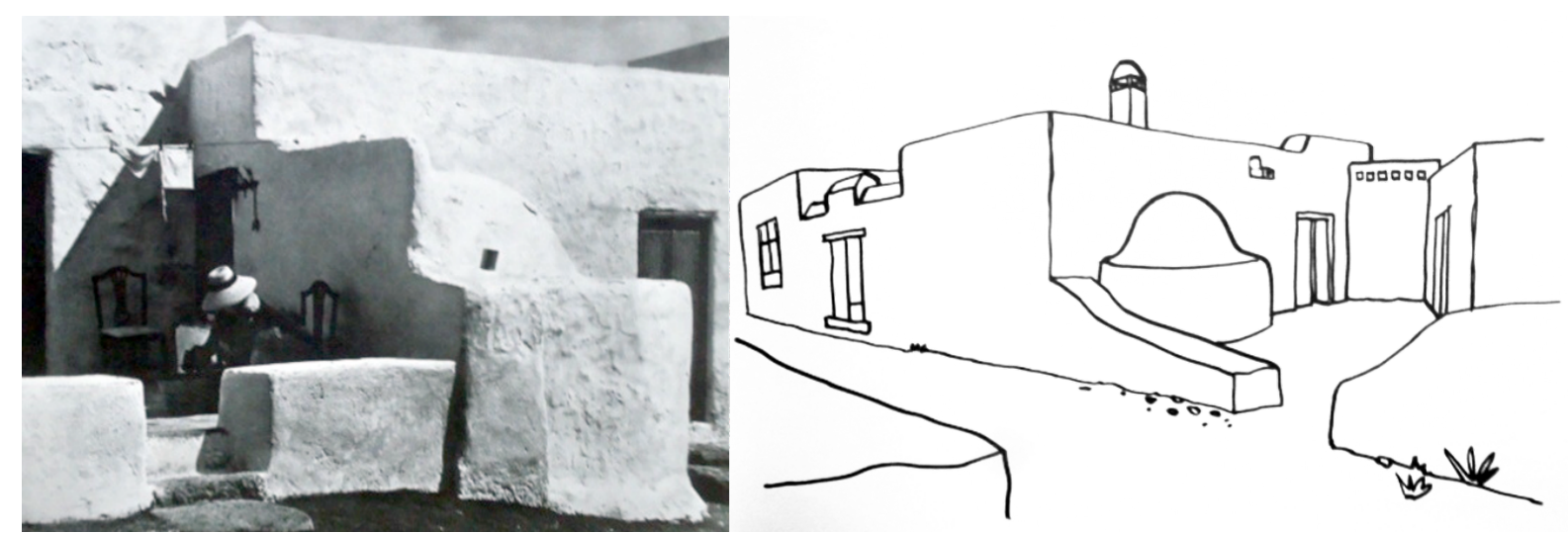

Figura 1. Foto y dibujo de arquitectura tradicional lanzaroteña. Manrique, 1974.

El turismo, según la OMT, "está considerado una actividad esencial para la vida de las naciones debido a su repercusión directa sobre los sectores social, cultural, educacional y económico", considerando, además, que es sostenible cuando "tiene plenamente en cuenta las repercusiones actuales y futuras, económicas, sociales y medioambientales para satisfacer las necesidades de los visitantes, de la industria, del entorno y de las comunidades anfitrionas". Esto refleja que la madurez que alcanza el sector está directamente relacionado con el cuidado de todo lo que compone el territorio turístico, en lugar de anteponer sus posibilidades económicas. Valiendo la redundancia, si no se protege todo aquello que lo hace diferente, cualquier territorio está abocado a la indiferencia.

Los territorios insulares son casos donde la cultura y el paisaje resultan excepcionalmente particulares. Como la misma estratificación histórica, que difiere en líneas temporales y civilizaciones en ella enmarcadas, la condición geográfica de las islas de Gran Canaria y Cerdeña se caracteriza por un aislamiento que ha acentuado su conservación. Agaete y Alghero, los casos de estudio, son ciudades costeras que se sitúan en el noroeste de sendas islas española e italiana. La primera posee una densidad demográfica casi ocho veces superior, con una afluencia turística anual que supera a la de Cerdeña en un 35\% dentro de un territorio con una extensión quince veces inferior. Esto ofrece una idea clara de las diferencias de presión urbanística a la que ambos territorios están sometidos. Aunque Cerdeña se encuentra en el centro del mar Mediterráneo, no cuenta con unos vínculos turísticos o mercantiles internacionales tan fuertes, lo que ha provocado un mayor hermetismo a todas las escalas. El fuerte impulso económico derivado de la apertura de Gran Canaria ha tenido como repercusión una intensa urbanización de la costa para satisfacer la gran demanda turística y una multicultural evolución social.

Parece contradictorio hablar de la preservación de una cultura que se ha moldeado a través del paso de diferentes culturas externas (sobre todo en el caso de Cerdeña), pero no se defenderá en este texto su inmovilismo, sino su atención y puesta en valor, para que sea su población local, que conoce y transforma su territorio, el mayor beneficiario de su evolución.

\section{La democratización del proceso de planificación: paisaje y cultura local como bienes comunes}

El paisaje y la cultura de un territorio están directamente relacionados con su interés turístico, lo que comporta la idea de ser elementos económicamente explotables. Ambos son, por definición, públicos, lo que los convierte en bienes comunes que debieran ser gestionados en favor del colectivo propietario, compuesto en este caso por la población local. Existen diferentes formas de tutela de un bien común (como agentes organizadores se postulan la administración pública, un sistema autónomo de acuerdos entre los propietarios o un término medio entre ambos) y su elección se puede supeditar a una serie de factores tales como su envergadura, su potencia 
económica o el número de implicados (Ostrom, 1990). No se trata ahora de discernir cuál es mejor, sino de componer una metodología para poner en valor esos bienes comunes que pertenecen y forman parte de la población local, lo que terminará influyendo en la evolución de su propia planificación.

\subsection{El beneficio de los implicados}

No se trata de componer una imagen terrible del turismo de costa. Tampoco de hacer de sus agentes económicos los nuevos parias del urbanismo. Algo que ha quedado claro de los trabajos de Ostrom sobre la gestión de bienes comunes es que dependen de todos y, por definición, todos tienen el deber de conservarlos para evitar perjuicios en futuros aprovechamientos. La solución requeriría un amplio y urgente debate entre las partes implicadas: propietarios del suelo, administración pública, urbanistas, promotores, población local, turoperadores, proyectistas, potenciales usuarios, etc.

En este contexto es imposible poner de acuerdo a tantos agentes intervinientes, donde la voluntad de la población local suele estar supeditada a la administración pública, que a su vez trabaja bajo la presión de las exigencias privadas para llegar a un consenso que tiene por objetivo la mayor explotación de los recursos urbanísticos y la economía de recursos. En este punto se plantea la opción de introducir un catalizador que fuerce a la administración a trabajar a favor de los residentes, aunque sean los extranjeros quienes representen el sector de mayor desarrollo económico.

No se puede proclamar que una mayor afluencia turística sea siempre mejor para el territorio y su población. Uno de los mayores problemas es la involuntaria gentrificación producida por los visitantes, ya que su presencia encarece la vida de la comunidad hospedante, con un efecto aún más pronunciado si existe una evidente desigualdad económica entre los países de procedencia y destino. 0 la dificultad, en territorios con turismo estacional, de disfrutar de sus playas o terrazas ya que con la llegada del buen clima - y con él mayor motivación para el ocio extra doméstico-, la densidad de turistas dificulta a los residentes el verdadero disfrute de su tierra.

Ahora bien, ante la redacción de un nuevo proyecto para la planificación de un área turística, ¿quiénes serían sus directos beneficiarios? Si la administración pública se basa en criterios relacionados con la propia población local y su territorio, además de realizar las usuales tareas gestión participativa, se puede aspirar a una planificación más acorde con los elementos culturales que históricamente se han desarrollado en ese territorio, responsables de lo que constituye actualmente su cultura local, que siempre ha estado - y estará- fuertemente vinculada al paisaje. De esta manera, desde el punto de vista de la planificación, la cultura local podría hacer por la población lo que el paisaje hace desde hace años por el territorio: representar los valores verdaderamente representativos de los mismos.

\subsection{Una cuestión de identidad: sociedad y territorio hacia una nueva geografía cultural}

A principios del siglo pasado era la unidad formada por cultura y naturaleza la que constituía el elemento básico para el análisis del paisaje en geografía (Sauer, 1925), donde se ignora el papel que los individuos tienen como agentes humanos a la hora de tomar decisiones y de negociar e imponer limitaciones a otros individuos o grupos. Pero la mayor interacción entre diferentes culturas favorecida por los cambios políticos y económicos acaecidos posteriormente, unidos a la amplia difusión y abaratamiento del transporte aéreo (que potencia radicalmente el turismo desde los años 50), ha permitido desarrollar una nueva teoría que involucra al individuo como pieza fundamental en la evolución de su territorio y viceversa, o lo que es lo mismo, su identidad. Esta evolución de la geografía cultural se desarrolla a través de varios conceptos, entre los que se encuentran la ecología cultural o la geografía social. Estos dos conceptos están íntimamente relacionados con el caso desarrollado en el punto anterior y la teoría expuesta en Spaces of hope (Harvey, 2000), donde analiza el porqué del fracaso de las diferentes utopías históricas y establece un análisis de la construcción de nuevos espacios sociales capaces de impulsar el cambio social como contrapartida a los escenarios de libre mercado.

Los espacios de mayor intensidad paisajística, sucumben a la presión económica y quedan fagocitados por el turismo masivo. La población local, ante un claro proceso de gentrificación, se 
ve empujada hacia áreas menos apetecibles. Las residencias en las consideradas mejores áreas (playas, zonas elevadas con vistas, centros históricos, etc.) son alquiladas e incluso vendidas paulatinamente a los turistas, con lo que la histórica relación cultura-paisaje-población local se va dificultando. Y no se trata sólo de residencia, sino de los propios espacios libres e, incluso, varios de los llamados públicos, que terminan privatizándose por los usos que en ellos se desarrollan, aunque sigan quedando abiertos y espacialmente accesibles al público. Todo ello exige volver a una verdadera justicia social, donde se produzca una distribución equitativa de la población local y turista. Así, de manera natural, el turismo se mezclará con la sociedad local, influyendo — como es inevitable- en la cultura local, pero sin aislarla, obviarla o simularla.

El Paisaje Protegido de La Geria (Figura 2), en Lanzarote, revela un paisaje cultural donde el territorio ha sido modificado para proteger las vides del viento y aprovechar la humedad que se deposita en su terreno volcánico, confiriendo al vino resultante un característico sabor. El caso de esta isla es especialmente esclarecedor en este ámbito: una isla con una fisionomía tremendamente particular que se mantuvo al margen de los primeros años del desarrollo turístico de Canarias. Su posición de observador distante, permitió a Manrique comprender los procesos que se desarrollaban en Gran Canaria y Tenerife y que tan intensamente afectaban a su territorio. La clara oposición del artista a ese modelo de desarrollo marcó el porvenir de toda una isla que en gran medida conserva hoy una fuerte identidad propia, evidenciando cómo arte, arquitectura, urbanismo y territorio están íntimamente ligados a la cultura local, y que la puesta en valor de los elementos, estructuras y sistemas que componen la identidad local es en todo momento positiva para el territorio y su sociedad.

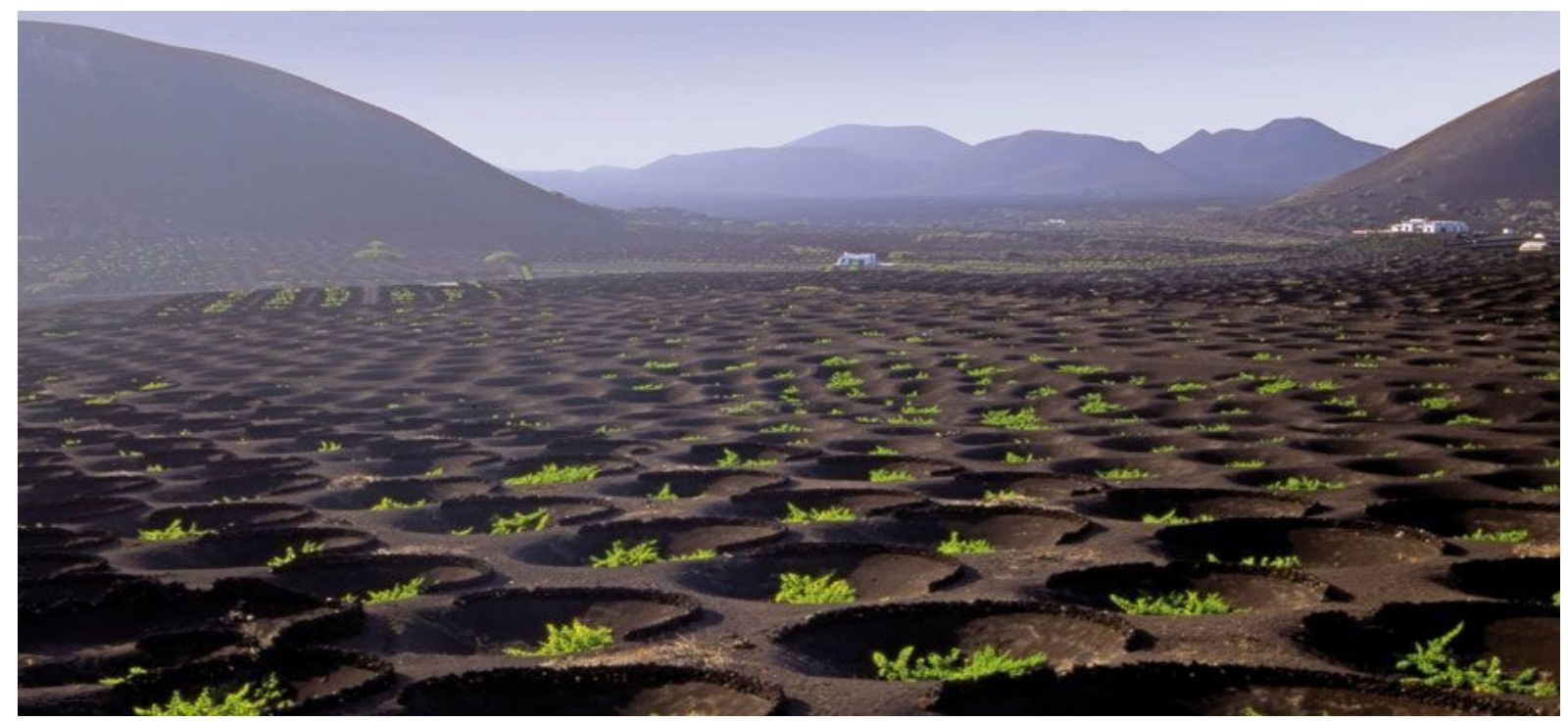

Figura 2. Paisaje Protegido de La Geria. <http://www.holaislascanarias.com/espacios-naturales/lanzarote/paisajeprotegido-la-geria>. [Acceso en 2016].

\section{3. (Re)composición del territorio a través del imaginario colectivo}

El paisaje no es un objeto estático sino un sujeto dinámico, un proceso continuo potencialmente conflictivo, incómodo y desordenado (Bender, 2001), capaz de enmarcar nuestro espacio de vida entrelazando naturaleza, historia, cultura y sociedad. El "lugar" cambia constantemente, lo que exige para su desarrollo consciente una relación constante con su representación colectiva. Ya no se trata sólo del espacio físico, sino de una idea que involucra también lo intangible, que necesita un sujeto activo capaz de tejer los complejos lazos entre lugar y contexto (Pittaluga, 2003). Porto Cervo, en el noreste de Cerdeña, es un ejemplo de composición arquitectónica y urbanística que la población insular ha terminado de creer como propia. La villa creada a principio de los años 60 fue diseñada por el arquitecto Luigi Vietti según la iniciativa del príncipe Karim Aga Khan de construir un nuevo destino para el turismo de élite, tomando la Costa Azzurra como referencia. El resultado, más allá de su calidad como propuesta arquitectónica, es una nueva y falsa imagen colectiva de arquitectura vernácula (Figura 3), tanto en lo que concierne a gran parte de los residentes como de los turistas, apareciendo constantemente en las fotos de folletos y anuncios que tengan a Cerdeña como destino turístico. 

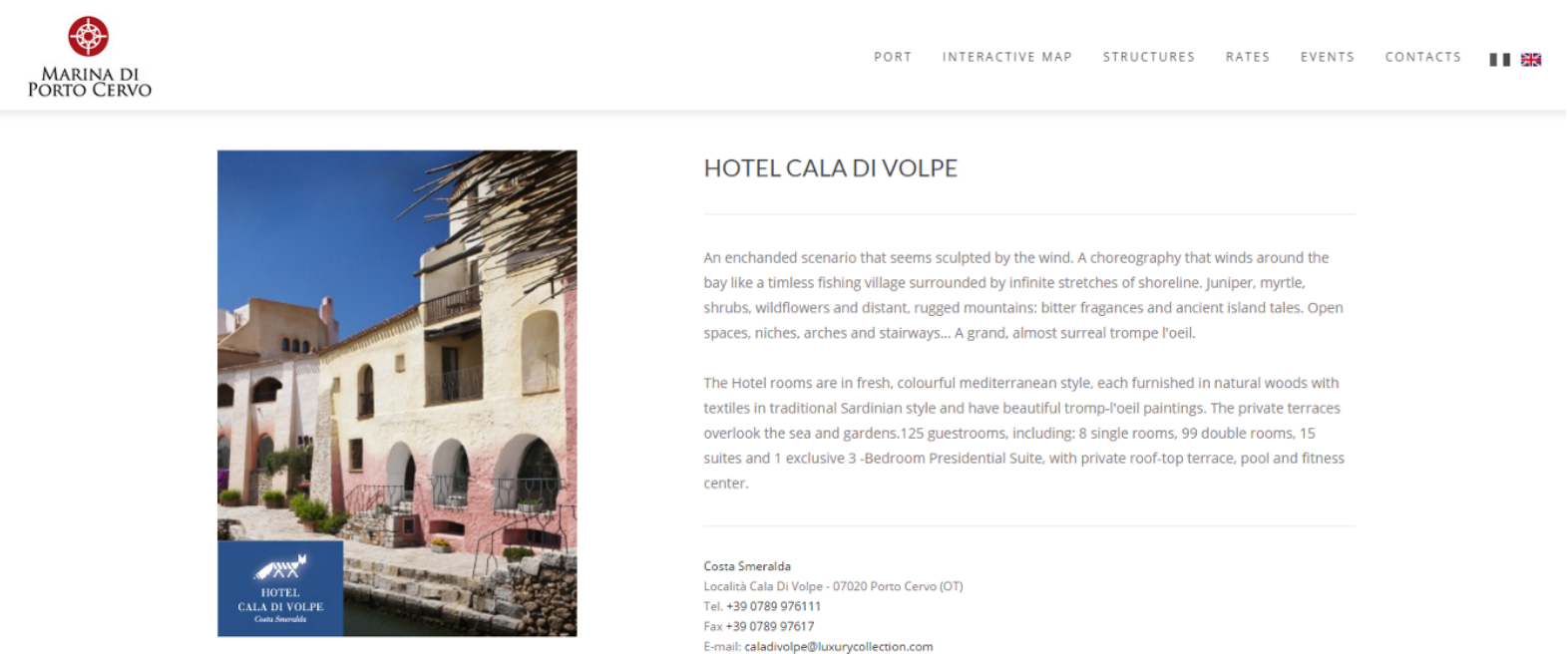

HOTEL CALA DI VOLPE

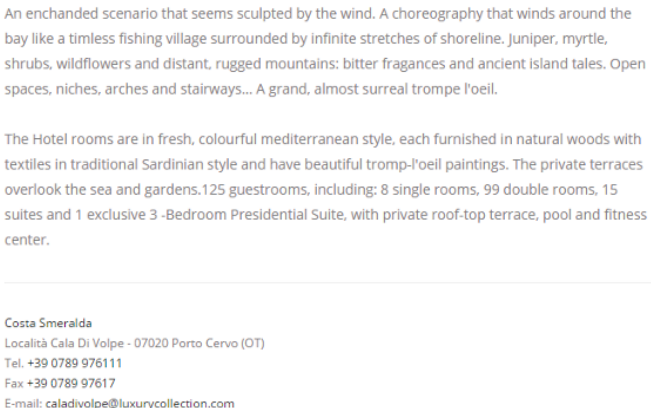

Figura 3. Web de la Marina de Porto Cervo, cuyo hotel Cala di Volpe se define como "un atemporal pueblo de pescadores rodeado de infinitos tramos de costa". < http://www.marinadiportocervo.com/structures/hotels>. [Acceso en 2016].

El problema del reconocimiento del verdadero paisaje, sea éste natural o urbano, radica en su relación con la evolución del territorio al que pertenece y a la imagen instalada en el subconsciente colectivo. Elementos que no hayan sido alterados quedan como algo que pertenece realmente al paisaje local, identitario, pero otros nuevos y formalmente ajenos, quedarán aborrecidos. La costa ha permitido el desarrollo de la pesca, y su inherente influencia económica, como lo ha hecho también el espacio rural con las zonas de cultivo. Se trata de áreas históricamente relacionadas con aspectos cotidianos de la vida de los residentes y que forman parte de un sinfín de anécdotas que se establecen dentro del marco común de la población local y que ésta asimila como intrínsecos a su propia condición. Existe incluso, dentro del imaginario turista, un abanico de ejemplos de lo que los individuos que componen la sociedad local pueden ser: "los canarios están aplatanados", porque viven un clima tropical con buen tiempo y es la imagen idílica de la tranquilidad y el relax, "los sardos son muy suyos", debido a la condición insular de Cerdeña y a su separación del resto del territorio italiano.

Los elementos más relevantes y distintivos que componen un territorio se atribuyen asiduamente al paisaje natural (montes, ríos, playas, llanuras, bosques, etc.) pero el paisaje urbano tiene, en todo caso, un papel fundamental a la hora de componer una imagen contemporánea de la evolución histórica de la sociedad local: arquitectura (representada a través de iglesias, viviendas, ayuntamientos, fuertes, almacenes...), mobiliario urbano (bancos, quioscos, farolas, macetas, fuentes...), el trazado y construcción de las calles, la tipología y disposición de plazas, parques y jardines, los puertos con sus barcos, grúas, zonas de almacén, etc. Estos elementos narran por sí mismos el día a día de las diferentes generaciones que lo han vivido, cuya historia trasciende el transcurso del tiempo.

\subsection{Directrices generales para una planificación en continua evolución. Mirar al pasado para proyectar el presente}

No es necesario explicar la relación entre cultura, paisaje y territorio, cuando la historia afirma rotundamente que las comunidades locales constituyen la fuerza motriz de la misma. Modificaciones del perfil de costa para adecuarse a la presión urbana, procuración de muelles para la supervivencia de una población de tradición pesquera, transformación de marismas en áreas de cultivo, creación de ciudades que dependen de barrancos y sus aguas, áreas que presentan una orografía accidentada e inviables para la agricultura que se especializan en productos derivados de la trashumancia. Todas acciones del hombre, sobre el paisaje, como respuesta a su necesidad de acomodar sus costumbres al territorio que habita y que se presenta hoy como patrimonio.

La Carta Internacional sobre Turismo Cultural del ICOMOS (Comité Español del Consejo Internacional de Monumentos y Sitios) estableció en 1999 una serie de objetivos para la gestión del turismo en sitios con patrimonio significativo. La composición de sus propuestas clave se basa en estimular la gestión y conservación del patrimonio tanto por parte de la comunidad anfitriona como de los 
visitantes, una correcta relación de sostenibilidad entre los intereses de conservación del patrimonio y los de la industria turística y la creación de estrategias para la interpretación de sitios con patrimonio. Esta clara inclinación hacia la gestión y protección del legado de una sociedad demuestra que incluso desde las administraciones públicas existe la necesidad de conservar un recurso que produce contemporáneamente economía y bienestar social.

La planificación turística de un entorno cuyo principal reclamo se compone de patrimonio paisajístico y cultural, requiere una aproximación diferente a la usada en el resto de territorios expresamente creados por iniciativa turística, haciendo necesario un ejercicio de interpretación que ponga en valor ambos aspectos dentro del contexto territorial. Cuando los elementos culturales que definen la comunidad local se tejen junto al paisaje se crean nuevos ámbitos de percepción espacial, lo que permite establecer un nuevo orden territorial que manifieste por sí mismo su propia identidad, quedando representada la voluntad de esa comunidad, en el proceso de planificación, a través de la evolución histórica de esa misma identidad.

\section{Agaete y el barranco como unidad básica radial de la composición del paisaje insular}

El municipio de Agaete, con una fuerte tradición tanto agrícola como pesquera, se sitúa en el noroeste de la isla de Gran Canaria (Figura 4), al final de la vía de acceso rápido que circunscribe casi totalmente la isla, desde donde existe además conexión marítima con la otra isla principal de la comunidad autónoma, Tenerife. Esta facilidad de acceso y lo apabullante que se muestra el paisaje cuando se llega, hacen de Agaete un pueblo por el que todo turista debe pasar.

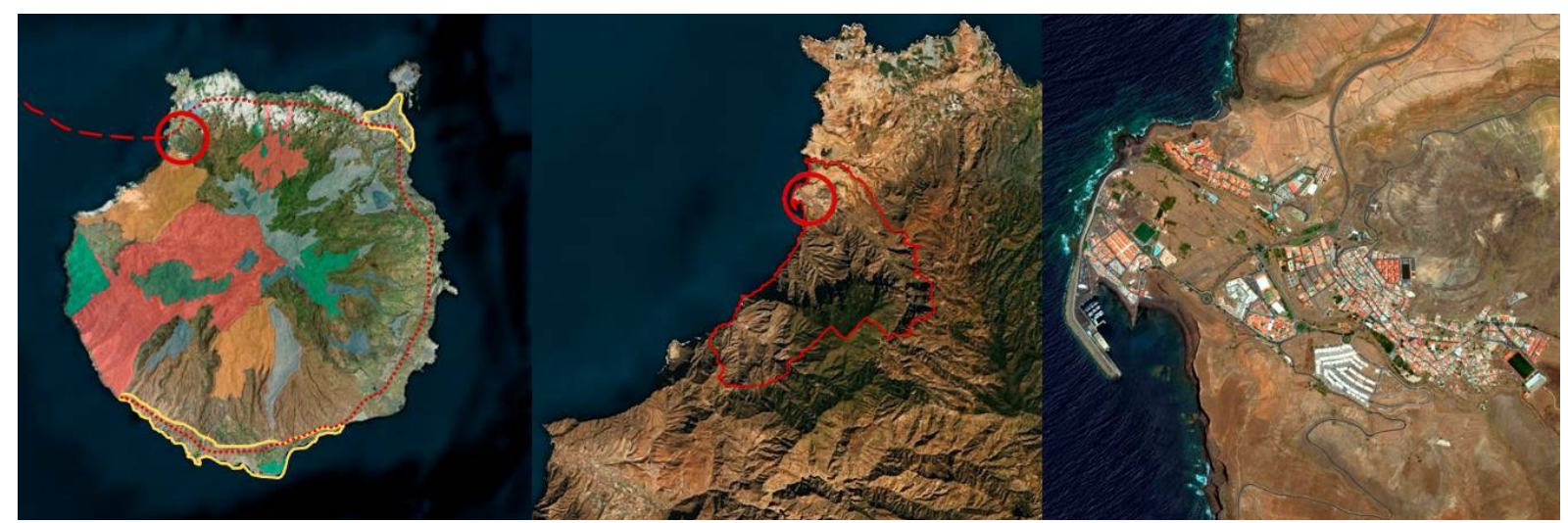

Figura 4. Gran Canaria, limite municipal y Villa de Agaete. Elaboración propia con ortofotos de www.bing.com/maps

Ante un eventual deseo de acceder a algunas de las pocas playas de la isla que aún no hayan sido intervenidas por cualquier forma de acción antrópica, se puede continuar hacia el sur por una carretera extremadamente sinuosa y de menor velocidad, lo que permite una afluencia más contenida de turistas y la conservación de un paisaje natural de valores incalculables. En cambio, si lo que se busca es conocer la realidad rural, un impresionante valle se desarrolla a lo largo de otra carretera que atraviesa el núcleo histórico interno y que pone en contacto al visitante con el mundo agrícola local, enmarcado en un espacio de gran calidad paisajística y ambiental.

Quizás lo más llamativo de este ejemplo, tanto en comparación con otras ciudades costeras de Gran Canaria como de Cerdeña, es que, si bien es cierto que hay una importante afluencia turística, ésta no se traduce en el esperable desarrollo urbanístico, ya que la mayor parte de los turistas que la visitan no se alojan en Agaete. Poseer esa potencialidad pero carecer de desarrollo presenta este área como un interesantísimo marco sobre el que trabajar.

\subsection{Des-arrollo turístico en Gran Canaria}

Islas Canarias. Enclave histórico entre Europa, África y América. Situadas en la proximidad de la costa oeste de Marruecos, y destino preferido por miles de turistas al año gracias a sus incuantificables cualidades paisajísticas y culturales, sufre, desde hace 50 años, un importante problema de ocupación 
masiva y acelerada del litoral a través del tejido urbano de nueva creación destinado al alojamiento turístico.

En los años 60-70 se construye en un contexto de ineficaz legislación en desarrollo urbanístico y, sobre todo, paisajístico y ambiental, una trama urbana descontextualizada, irreconocible en relación no sólo al territorio donde se construye, sino en la relación entre sus piezas internas, con una arquitectura que nace como respuesta al estilo vacacional de la época. Un momento en el que no existe iniciativa administrativa o pública para la creación de un funcional, articulado y verdadero espacio público, donde se produce un importante cambio morfológico del litoral en un corto periodo de tiempo para permitir el alojamiento masivo de turistas de sol y playa.

Playa del Inglés (Figura 5), en el sur de Gran Canaria, ejemplifica perfectamente este desarrollo. Una ciudad turística de nueva creación con el fin último de alojar la masa turística donde la presencia de un verdadero espacio libre público - aparte de la playa- es un sueño, pues la superficie de espacio no privado se compone de vías de acceso rodado en un abrumador porcentaje. Totalmente ajena al contexto cultural y territorial, se desarrolló junto a las dunas de Maspalomas, frágil área de inmensurables valores paisajísticos y ambientales.

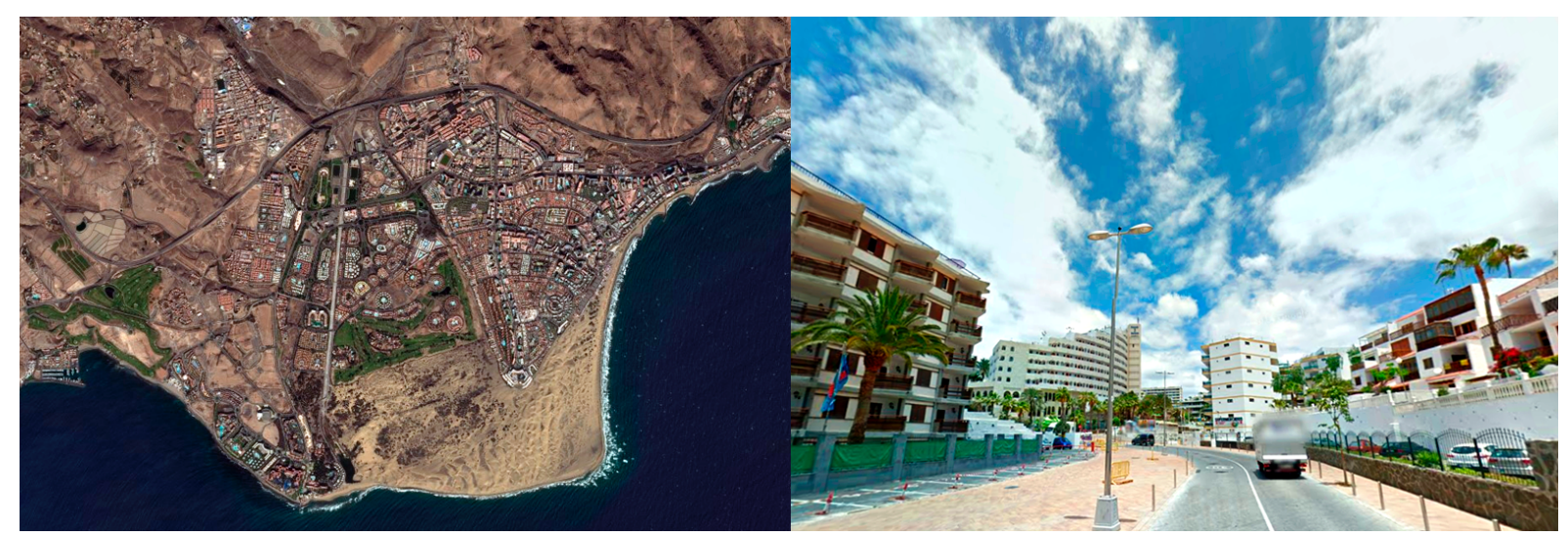

Figura 5. Ortofoto y foto de Playa del Inglés. Google Earth, 2016.

Después de este intenso inicio del turismo - pasados los años 70-, empieza a vislumbrarse un cambio paulatino hacia la cohesión y la calidad de los nuevos trazados, para tratar de revertir el efecto de la normativa anterior, que constituía básicamente una serie de preceptos y directrices muy rígidos. Por lo que no es hasta 1999, cuando el sector turístico entró en crisis (aunque la construcción de nuevo suelo no se detuvo), que se inicia en dos de las islas más áridas, pero más buscadas por el turismo de playa, una nueva lucha: 'Ni una cama más'. Este cambio de conciencia colectiva frena la construcción y pone de relieve los valores paisajísticos — que no sean constituidos esencialmente por las playas- y culturales como otra forma de entender el turismo, tal y como ya había entendido y propuesto el artista 'conejero' (de Lanzarote) un cuarto de siglo antes, lo que dio paso a un plan integral que aborda estas cuestiones a una escala insular para, después, proponer desarrollos pormenorizados más adecuados a cada ámbito y paisaje concreto.

No es lo mismo crecimiento que desarrollo, aumento cuantitativo que transformación cualitativa, así que las actuales Directrices de Ordenación General, como reflejo de la renovada preocupación del ciudadano canario en materia de paisaje, pretenden contener el consumo de suelo y promocionar un uso más eficiente del que ya esté urbanizado, al tiempo que se cualifica al territorio de complejidad funcional y morfológica, con especial atención al paisaje.

\section{2. Último enclave de la circunscripción insular}

La propia administración pública, como reflejo de este cambio de dirección turística, ha aprobado recientemente la revisión del Plan Insular de Ordenación de Gran Canaria, donde se impide el aumento del número de plazas hoteleras de las áreas más turísticas del sur de la isla, mientras establece nuevas camas en las áreas rurales y costas del norte y oeste (desde Arucas hasta La Aldea). Una apuesta por un turismo más maduro y con inquietudes que abarcan un espacio

(C) Labor \& Engenho, Campinas [SP] Brasil, v.10, n.3, p.232-248, jul./set. 2016. 
mayor que el de la playa. La posición de Agaete en el noroeste de la isla, como guinda del pastel que supone la continuidad paisajística de la costa norte, tiene el potencial de asumir una mayor carga turística y presentar los entornos naturales que posee, entre los que se encuentran las áreas, tanto rurales como costeras, menos antrópicas de la isla.

Agaete, al igual que la isla, compone su topografía a base de barrancos que devuelven al mar el agua que cae en el centro de la isla. Dos de ellos, el de Agaete al norte y el del Risco al sur, enmarcan el municipio y comprenden sus dos asentamientos urbanos. El espacio se compone a nivel perceptivo de una plataforma elevada, Tamadaba, que se asoma al mar a través de altísimos acantilados, dibujando el paisaje entre el núcleo histórico costero de Agaete, el Puerto de Las Nieves, y el barrio de El Risco (Figura 6).

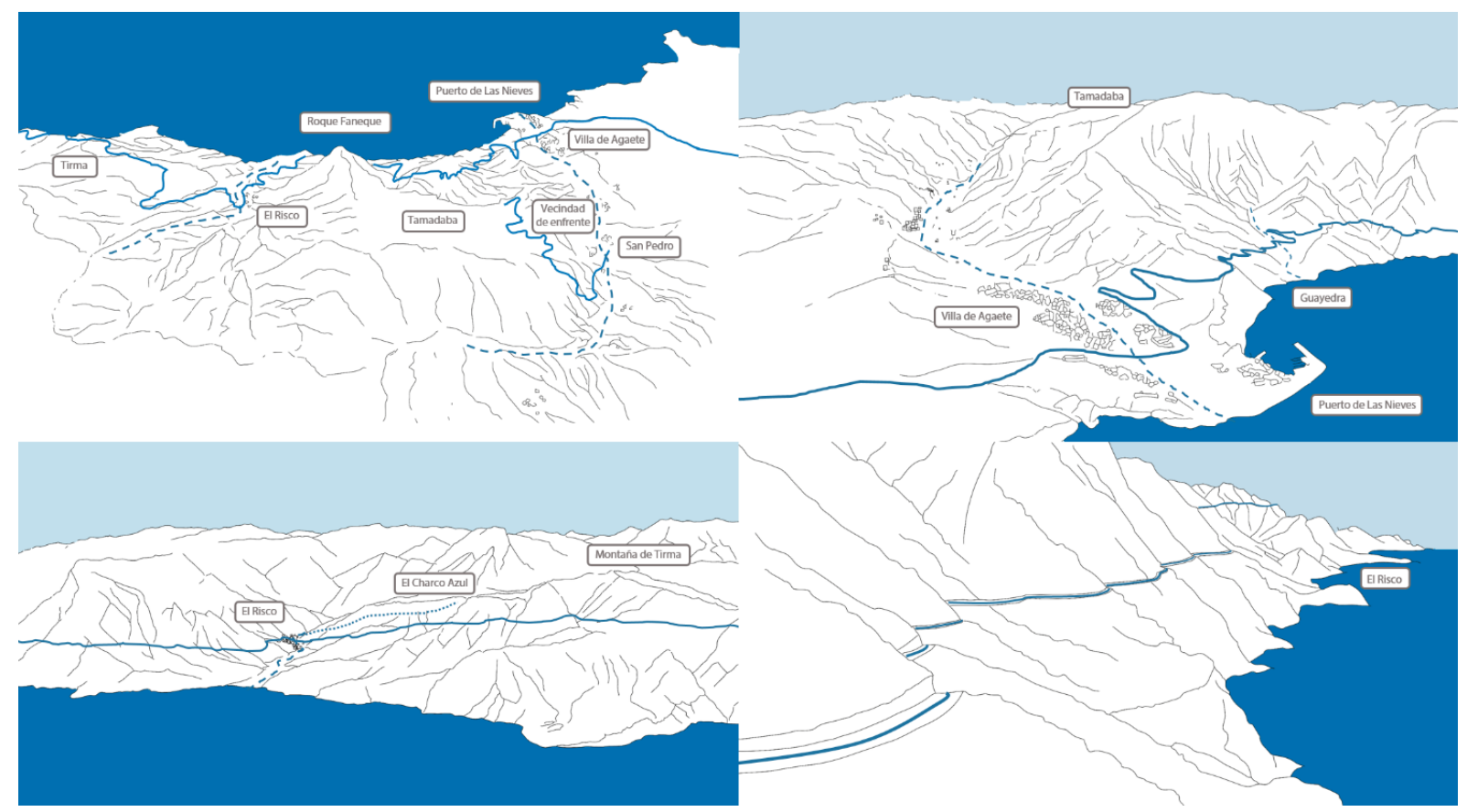

Figura 6. Paisajes de Agaete. Elaboración propia.

El Parque Natural de Tamadaba se encuentra dentro de la Reserva de la Biosfera de Gran Canaria, conteniendo innumerables valores ambientales y paisajísticos. El barrio de El Risco se encuentra dentro de este área, por lo que pertenece al nuevo programa de "Ecobarrios", con el que se pretende establecer un equilibrio entre el desarrollo socioeconómico y el respeto de los valores naturales y culturales de la isla.

Los barrancos que corren entre El Risco y el núcleo urbano de Agaete contienen, aparte de obvios valores ambientales - se encuentran prácticamente inalterados por la mano del hombre-, preciosos paisajes donde la vegetación autóctona acompaña al aventurero turista hasta la costa, regalándole playas de arena negra, en un contexto totalmente ajeno al de otras áreas turísticas. El camino merece el esfuerzo, pero la confirmación llegará con el atardecer de un sol que se esconde tras la montaña más alta de España. El Teide, con sus 3718 metros, saluda al turista ante la promesa de volverlo a ver si permanece en esta bella tierra.

La parte más urbana de Agaete da paso al Valle, donde el paisaje costero queda oculto tras las montañas que no pueden esconder el olor a sal suspendido en el aire. Su imagen rural y agrícola es el contrapunto perfecto al inicial empacho de costa, con pequeños núcleos residenciales y algunas casas diseminadas entre los cultivos, donde cafeto, naranjo y vid forjan un acuerdo con el suelo para crear los matices que harán recordar esta tierra.

\subsection{Cultura culeta}

Macleod dice que "el canario tiene sus pies en África, su cabeza en Europa y su corazón en Sudamérica" (Macleod, 2004, p.173). A la primera debe su posición geográfica y su cultura prehispánica, la 
segunda se relaciona con la llegada de los españoles y la consecuente adscripción al territorio europeo, y la tercera tiene que ver la continua emigración de canarios hacia Sudamérica como resultado de su conquista en el s. XV por parte de las coronas de Castilla y Aragón, cuya influencia se hace clara en los nuevos productos agrícolas (papa, millo o tomate).

Aunque la cultura canaria tiene un trasfondo común a todas las islas, han existido y existen evidentes diferencias entre ellas e incluso entre los diferentes territorios que las componen. A nivel regional es posible hablar del trabajo en barro, las pintaderas o la mitología aborígenes, de la arquitectura tradicional de origen hispánico, o de la gastronomía. Pero es importante, cuando se habla de un territorio concreto, explicar sus peculiaridades dentro el contexto común, ya que ayuda a entender los porqués de su evolución histórica y la razón de su unión a la población local.

El municipio de Agaete comparte frontera con el de Gáldar (una de las dos capitales prehispánicas) y está situado al final de lo que podría considerar como un corredor costero que prácticamente circunscribe la isla de Gran Canaria desde el sur, pasando por el este y el norte, lo que explica por qué existe una gran herencia cultural con la forma de patrimonio tangible. El característico territorio sobre el que se asienta Agaete, unido al hecho de estar ligeramente más aislado del resto de poblaciones, ha permitido el desarrollo de otros tantos elementos particulares que han derivado en una cultura fuertemente ligada al mismo.

Gran parte del patrimonio histórico de Agaete procede de la época prehispánica. Siguiendo la costa, desde el centro histórico hasta el risco, montículos y barrancos presentan restos de antiguos asentamientos aborígenes. Senderos usados hoy en día en el Valle para subir a Tamadaba u otras lomas son los antiguos pasos que usaba la comunidad aborigen. Existe además un rico folclore que ha trascendido hasta hoy y que supone el nexo de la población local con su tierra.

Los dos núcleos históricos, uno junto al mar y otro junto al valle, ilustran cómo la pesca y la agricultura han sido los pilares fundamentales de una sociedad que debate su corazón entre los mundos costero y rural. Su unión como un territorio único se establece, una vez más, gracias al barranco.

Hablar de Agaete es hablar de La Rama (Figura 7), fiesta que además es la perfecta unión entre cultura, paisaje y territorio. Independientemente de su absoluta certeza, la tradición popular habla del recorrido hecho por los aborígenes en momentos de sequía, portando consigo ramas que cogían en lo alto de Tamadaba y que debían llevar, bailando mientras las agitaban, hasta la costa, a modo de ofrenda a los dioses. Hoy en día dividida en dos tramos y fiestas diferentes, representa la expresión máxima del arraigo de la población local a su tierra, donde los participantes agitan las ramas mientras bailan al son de las bandas locales de Agaete y Guayedra, hasta llegar a la ermita de Nuestra Señora de Las Nieves para hacer la ofrenda.

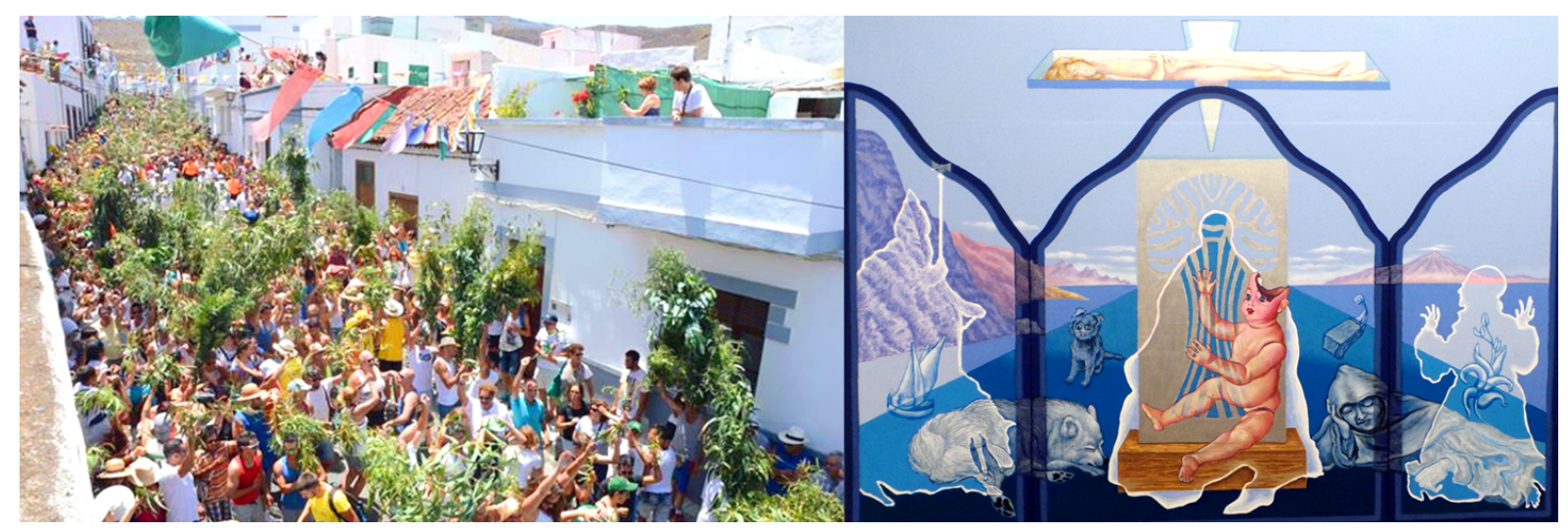

Figura 7. Fiesta de La Rama y "Virgen del Drago" (versión del tríptico de Nuestra Señora de Las Nieves de Joos van Cleve). Elaboración propia; Pepe Dámaso, 2013.

Existen otras fiestas, artistas, espacios urbanos, productos típicos, etc. Íntimamente ligados a Agaete: la romería, las obras de artistas como Pepe Dámaso y su trabajo sobre la cultura local, el puerto como reminiscencia del contacto entre Agaete y Flandes, el antiguo ingenio azucarero - 
cuya aporte económico ayudaría en la conquista a Tenerife-, o más recientemente el café y el vino, que ya forman parte de lo que se entiende cuando se nombra a Agaete.

\subsection{Narrativa paisajística. Un orden territorial implícito}

El agua ha definido el territorio insular grancanario a través de los ejes radiales que suponen los barrancos (Figura 8). Y es precisamente este elemento el que compone, a modo de postal que se repite una y otra vez, el paisaje de Agaete y que, además, pone en relación la costa y el entorno más rural.

No se puede decir que haya área física de Agaete que no posea paisaje pero, a modo de esquema que permita entender la percepción de las unidades de paisaje que componen el territorio, se diferencian cinco áreas (Figura 8). La 01 pertenece al espacio de Tamadaba, situado en lo alto de los acantilados que dominan todo el paisaje y en posesión de un gran bosque de pino canario. La 02 está constituida por el Valle de Agaete, se conecta con el anterior a través de senderos y restos de poblaciones aborígenes y su paisaje queda enmarcado por su topónimo, en donde se desarrolla la intensamente la agricultura. La 03 presenta el espacio más urbano, con sus dos núcleos históricos. La 04 se compone de una serie de acantilados y barrancos que llegan hasta el mar, donde también se encuentran muchos restos arqueológicos, y forma el nexo entre los grandes barrancos de Agaete y el Risco. Y es este último el que forma la 05, con un barranco que contiene el otro núcleo urbano del municipio y una amplia superficie de cultivo.

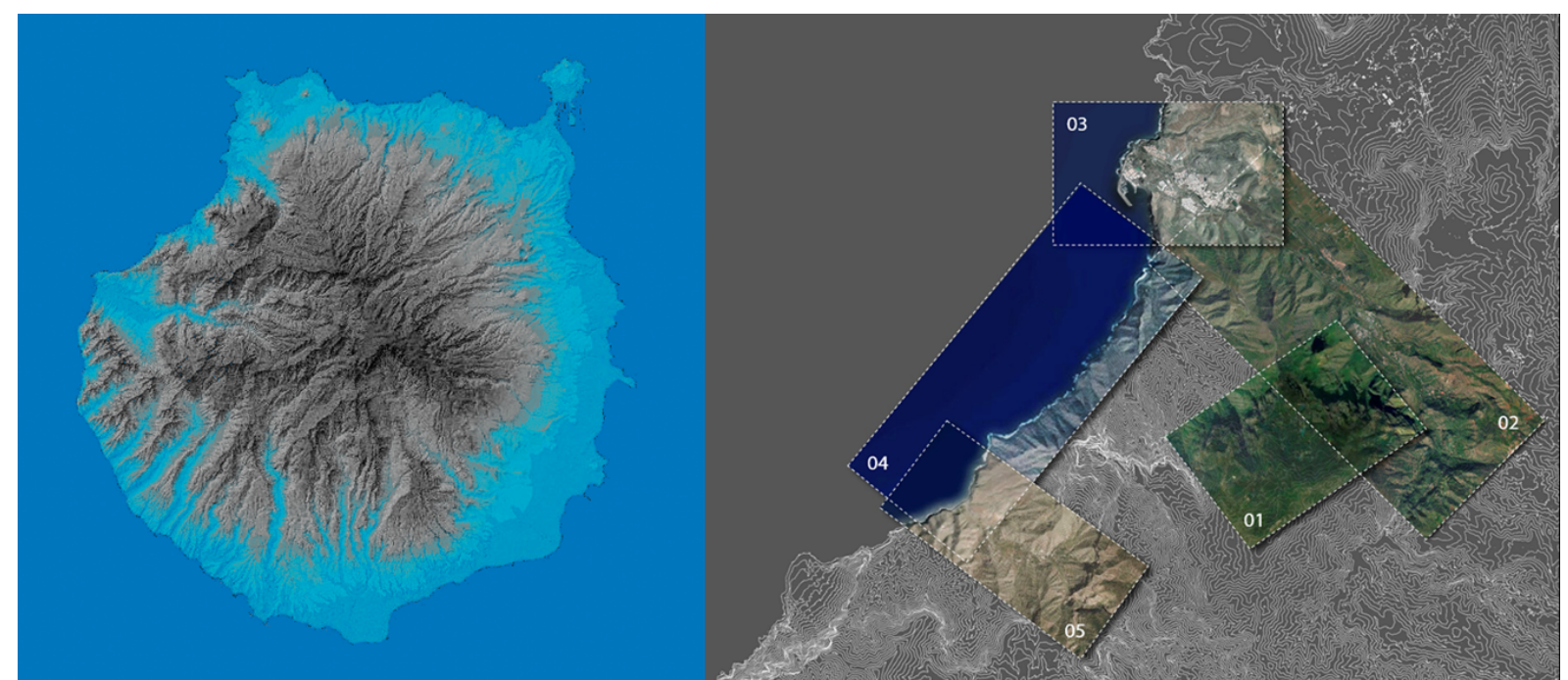

Figura 8. Barrancos de Gran Canaria y ámbitos paisajísticos de Agaete. Elaboración propia.

Como ejemplo de cuánto se influyen mutuamente cultura, paisaje y sociedad local, el área del barranco de Agaete se puede desglosar en varios ámbitos según la composición de los asentamientos urbanos, la estructura agrícola y la propia formación del barranco y la topografía que comporta. En la figura 9 se observa el conjunto y el desglose pormenorizado de estas capas, donde queda patente una clara relación entre ella y la forma del territorio: es el espacio de menor pendiente, compuesto por el lecho del valle, el que dibuja el área ocupada.

Las tres secciones elegidas muestran diferentes modos de ocupación según lo permita la topografía, y relegan paisaje y cultura a su propia condición territorial. El primer caso muestra los núcleos históricos, uno relacionado con el puerto, necesario desde la conquista para una economía basada en la exportación del azúcar, y otro relacionado con el valle, donde se situaba la mayor parte la población que trabajaba en las tierras del valle. Se sitúa en este área los espacios de relación social (plazas, parques e incluso calles) y los elementos arquitectónicos que ya forman parte de la imagen de Agaete. El segundo caso muestra un paisaje formado por las parcelas agrarias, algunos asentamientos residenciales y la imponente verticalidad del valle. La cultura aquí se refleja en los típicos productos agrícolas (cítricos, vino, café —única plantación en toda Europa-, etc.), que aprovechan la sombra de las montañas, el agua del barranco y la brisa del mar para ofrecer un carácter distintivo a su producción. El tercer caso evidencia cómo 
la forma del territorio condiciona fuertemente la población local y sus actividades: el espacio llano da pie aquí a empinadas laderas donde la agricultura deja paso a la producción de derivados lácteos de origen caprino, productos derivados de animales adecuados a este tipo de topografía.
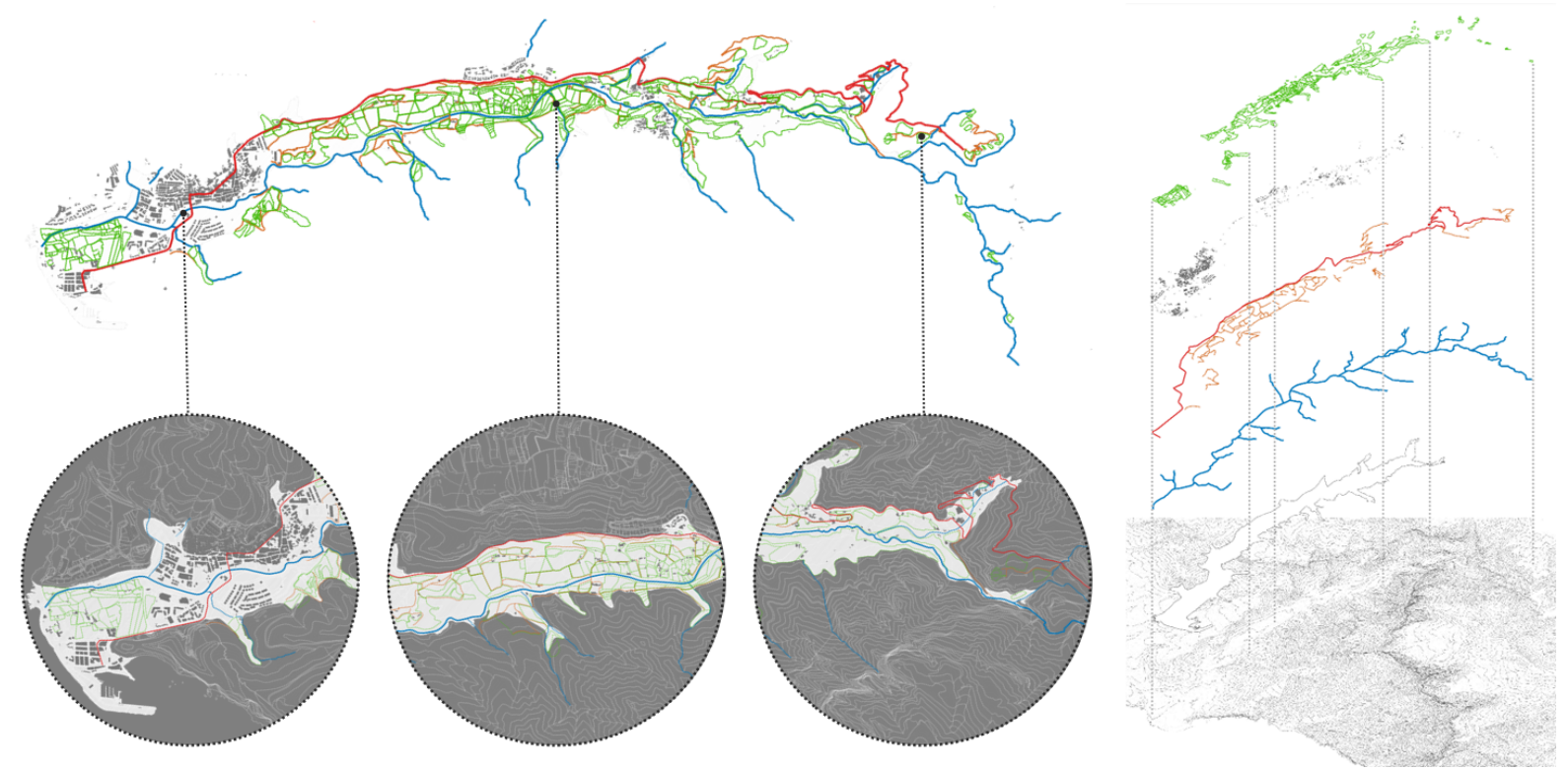

Figura 9. Análisis de la estructura territorial a lo largo del barranco de Agaete. Elaboración propia.

Entendiendo la composición de este territorio, su orden y estructura, se puede poner establecer las relaciones entre los elementos culturales y paisajísticos, permitiendo su puesta en valor turístico y repercutiendo positivamente en una población local que será capaz de reconocer esos elementos, establecerlos en una situación de mayor prioridad y luchar para que sigan componiendo su propia identidad.

\section{Alghero, donde la montaña emerge como monumento al paisaje natural sobre el plano antrópico}

Cerdeña no ha tenido el intenso desarrollo turístico de Gran Canaria y además ha sido el primer territorio italiano en producir una planificación específica para la protección del paisaje. La baja y controlada densidad de asentamientos turísticos a lo largo de su costa muestra un acercamiento menos agresivo con el paisaje que en la isla canaria. El municipio de Alghero, también al noroeste, se encuentra muy cerca de Sassari, una de las dos mayores ciudades de Cerdeña, con lo que la facilidad de acceso está garantizada, y además posee el único aeropuerto de la zona norte de la isla.

En Alghero, territorio de tradición agrícola y pesquera como en el caso de Agaete, el desarrollo turístico ha supuesto una extensión de la trama urbana y, con la llegada de aerolíneas de bajo coste, un fuerte impulso para la economía local.

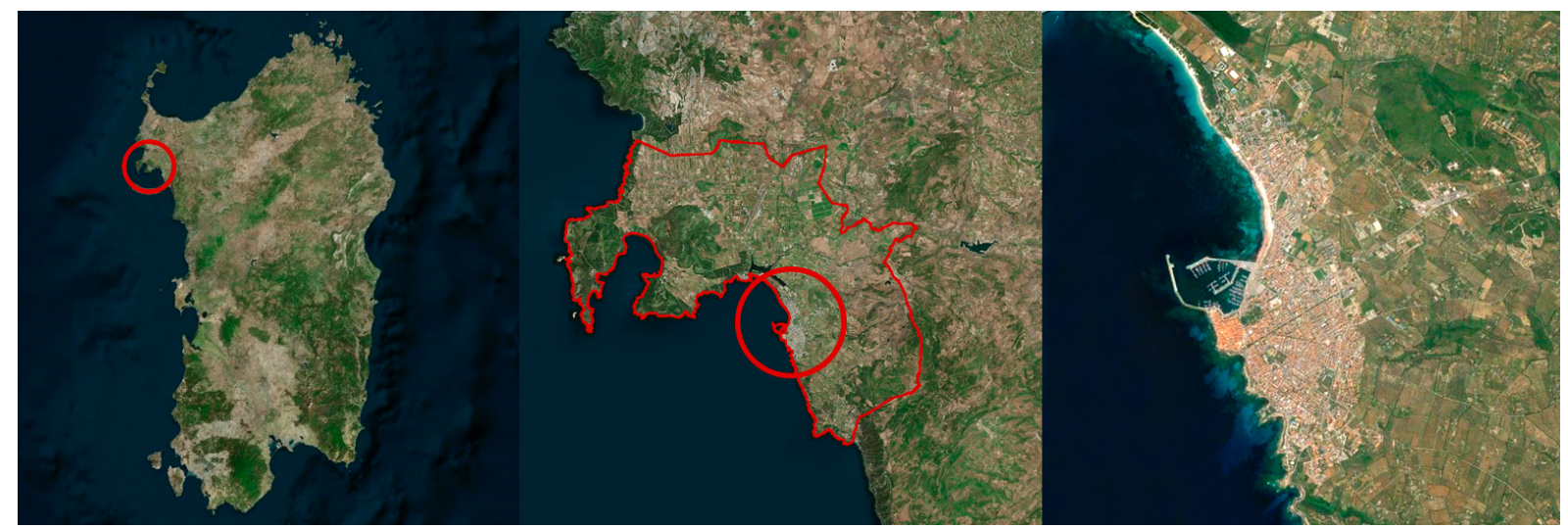

Figura 10. Cerdeña, limite municipal y ciudad de Alghero. Elaboración propia con ortofotos de www.bing.com/maps 


\subsection{Agricultura y turismo. Juntos pero separados}

La mayor diferencia con el turismo canario es la condición estacional del sardo. En abril y mayo empiezan a llegar los primeros turistas del año, extendiendo entre los meses de junio y septiembre el período de afluencia turística masiva. El resto del año, la actividad turística es prácticamente nula, lo que conlleva el temporal abandono de las instalaciones que tan activamente se usan en los meses de mayor actividad. En el caso de Alghero, la diferencia tan extrema entre los niveles de densidad turística se traduce en una ciudad que se encuentra muy activa en el periodo estivo y poco aprovechada en el invernal. Esto comporta importantes consecuencias en el modo de entender y vivir la ciudad (los servicios públicos funcionan según esta estacionalidad y no existe tanta oferta hotelera como se podría pensar inicialmente, funcionando mejor el alquiler temporal de segundas viviendas) y el territorio alguerés en general (las playas están vacías y disfrutan de su condición de paraje natural hasta que inicia el periodo vacacional).

Análogamente al área urbana, el otro pilar aparte de la playa donde se asienta la experiencia turística, existe - y esto se hace evidente a través de la inmensa cantidad de productos locales que se encuentra en los mercados - un importantísimo sector agrícola que se mantiene ajeno al turista, impidiéndole formar parte de la realidad socio-económica que ha constituido en la historia de Alghero. La ciudad se abre al mar, pero no implica a los turistas en el espacio agrario (Figura 11), lo que se percibe como una oportunidad perdida a la hora de mostrar parte de la cultura local.

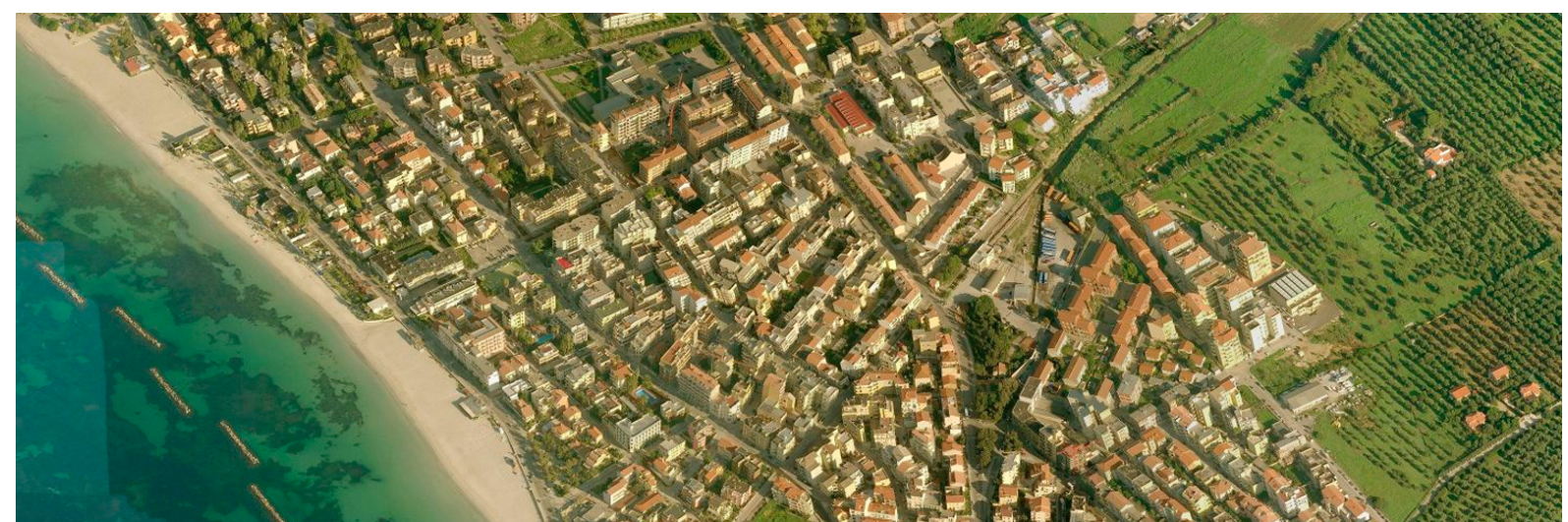

Figura 11. La ciudad de Alghero separa el área costera de la agrícola. <www.bing.com/mapspreview> [Acceso en 2016].

En un territorio donde aproximadamente el 70\% de la superficie está destinado a la agricultura y el centro histórico y las playas quedan superpobladas en temporada alta, parece necesario una redirección de los flujos turísticos desde la costa hacia el interior, poniendo en valor todo lo que contiene ese área menos urbana poseedora, además, de gran cantidad de patrimonio histórico en forma de restos de las antiguas civilizaciones que han vivido Alghero.

\subsection{Estratificación de civilizaciones. El patrimonio de Alghero}

La posición geográfica de Alghero ha permitido un fuerte vínculo con España, lo que propició por ejemplo la aparición de su propia lengua, el alguerés, como herencia de la dominación aragonesa. Cerdeña posee su propia lengua, el sardo, que no ha llegado a establecerse en Alghero, lo que deja entrever un ligero desligamiento voluntario en relación a la cultura del resto del territorio insular. Así, los alguereses poseen tradiciones, gastronomía e incluso formas de pensar que difieren en mayor o menor medida del resto de la población sarda.

La estratificación de las numerosas civilizaciones que han pasado por Cerdeña, y que han contribuido a un paisaje salpicado de elementos artificiales de varias épocas, se presenta como una poesía visual que retrata la historia de Alghero. La edad nuragica (hasta el s. II a. C.) tiene como más explícito representante al Complejo de Palmavera (Figura 12), una antigua villa compuesta de pequeñas cabañas de planta redonda, situadas en torno a un nuraghe complesso de tres torres en este caso- que servían a los nuragici. La presencia romana dejó construcciones como el puente que une Alghero con Fertilia a través del estanque de Calich o la villa y necrópolis de Santa Imbenia. La ciudad histórica remite su nacimiento a la voluntad, en el s. XII, de la familia 
genovesa de los Doria de crear un nuevo núcleo en la costa noroccidental de Cerdeña. El perímetro costero de la muralla -o bastioni- que la rodeaba dibuja actualmente una de las imágenes más características de la ciudad. Las torres (Figura 12) que se construyeron tras su conquista por parte de la corona de Aragón en el s. XIV exhiben la influencia arquitectónica española más evidente, ayudando a completar la imagen contemporánea de la ciudad.

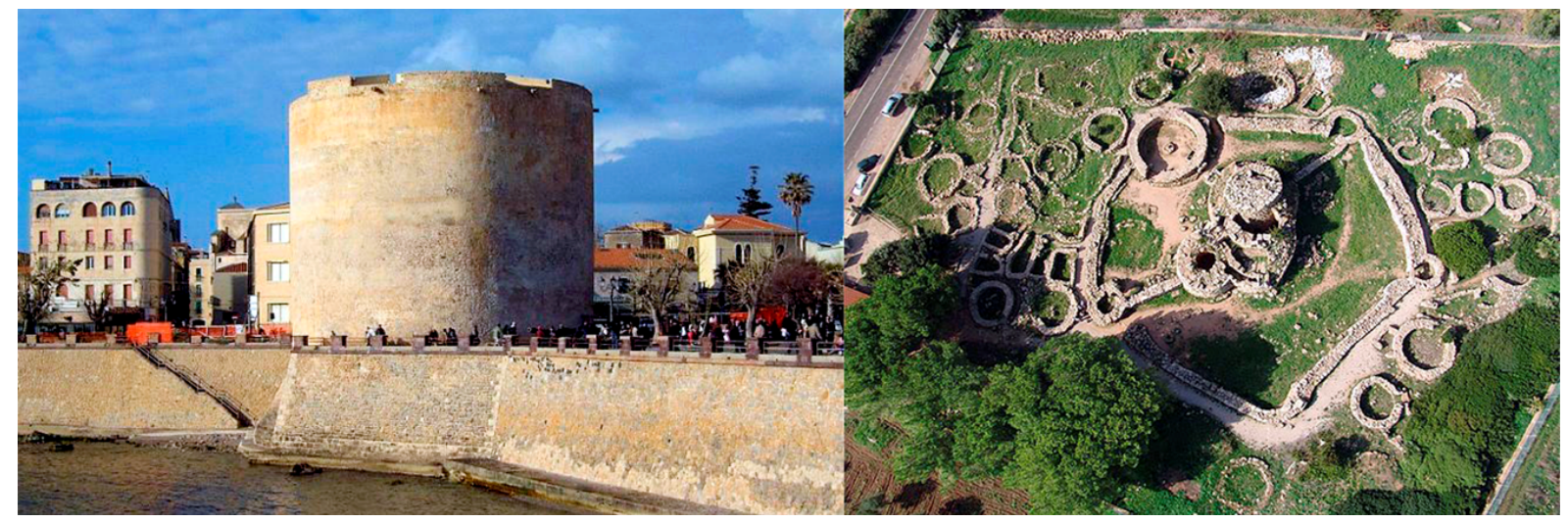

Figura 12. Torre Sulis sobre el bastión de Alghero y Complejo Nuragico di Palmavera. Elaboración propia; $<$ www.sardegnaremix.com>. [Acceso en 2016].

La cultura menos tangible se muestra en Alghero a través de las fiestas, idioma, gastronomía, arte, etc. La propia Semana Santa, con las procesiones como actividad fundamental, que llenan tanto de sardos como de extranjeros las calles de Alghero, marca el inicio de la temporada de turistas. El marisco es parte representativa de la cocina algueresa, donde comparte espacio con productos como los bien valorados vino o queso locales. El trabajo en coral es otro producto típico de Alghero y se puede encontrar en las numerosas tiendas del centro histórico. Diferentes artistas componen canciones, pintan o escriben sobre Alghero para mostrar su propia interpretación del territorio. Existe una gran variedad de elementos que componen la imagen misma de la identidad algueresa, cuya puesta en valor permite un más intenso acercamiento y protección de la misma.

\subsection{Un discurso único para la unión del paisaje natural, las áreas urbanas y las superficies de cultivo}

No es casualidad que el área antrópica, en forma de asentamientos urbanos o agrícolas, se haya establecido exclusivamente en la plataforma horizontal del territorio alguerés. En Cerdeña, durante la dictadura italiana, se realizaron tres grandes operaciones para transformar áreas pantanosas en áreas cultivables, donde estos territorios siempre llanos y vinculados directamente al mar dieron lugar a las denominadas áreas de bonifica. Parte de la operación que se hizo en la antigua región de la Nurra (al noroeste de la isla) se sitúa en Alghero y establece la estructura básica de su orden territorial (Figura 13).

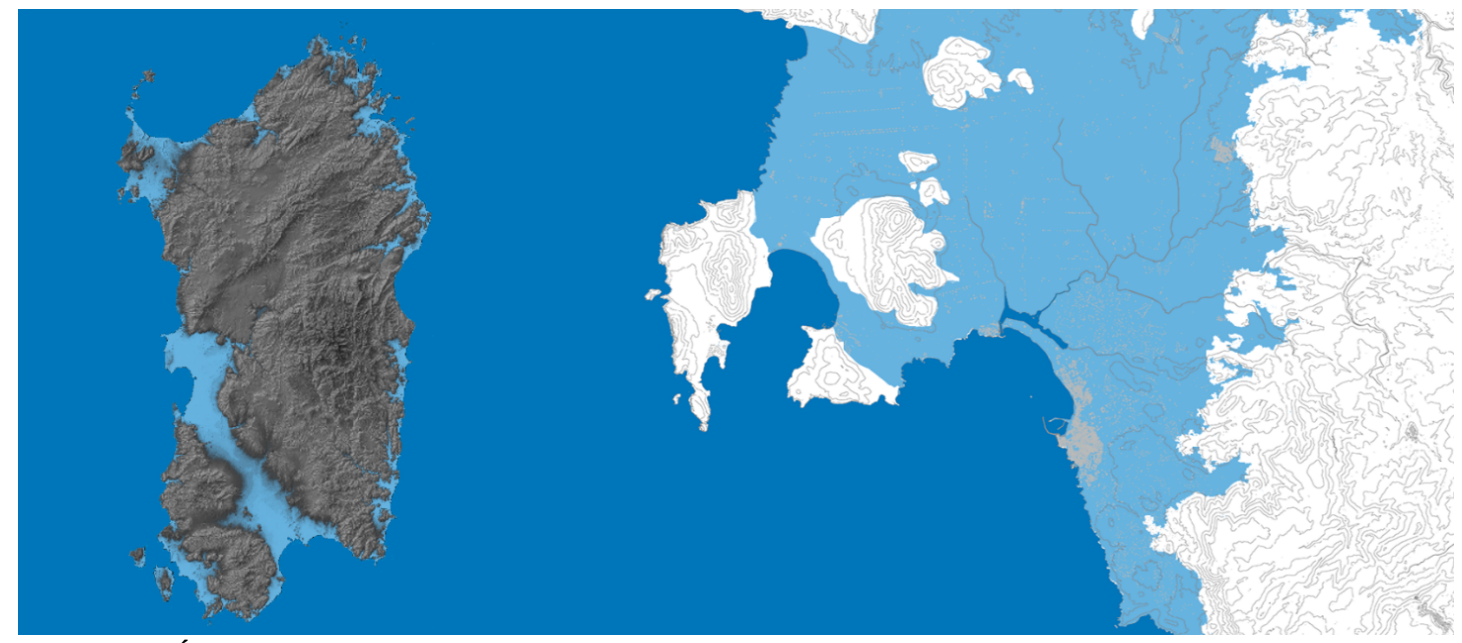

Figura 13. Áreas llanas de Cerdeña y Alghero. Elaboración propia. 
El paisaje queda entonces definido por esta plataforma antrópica horizontal y los elementos montañosos verticales enmarcan las tres bahías existentes. La montaña de Capo Caccia, la que más se adentra al mar, domina visualmente todo Alghero y es un símbolo natural del mismo. Este orden se presenta, al igual que en el caso de Agaete, a través del agua, con la diferencia de su estaticidad, pues parece que fuera el nivel del mar que se ha elevado, en lugar de establecerse a través de un barranco que corre.

El análisis de las estructuras que forman el territorio alguerés, vinculando los elementos culturales al orden paisajístico, permitirá establecer, como en Agaete, una reinterpretación del mismo, para una puesta en valor que refleje su verdadera identidad territorial.

\section{La mistura de realidades costera y rural. El ámbito para las estrategias de puesta en valor del territorio insular}

Las descripciones de Agaete y Alghero verifican su posición relativa dentro de un marco de mayor escala, el insular, donde comparten similitudes culturales y paisajísticas con el resto de un territorio que seduce al turista con el embrujo de la costa. Estas semejanzas, por lo tanto, pueden ayudar a extender el interés turístico hacia otros ámbitos tradicionalmente menos vinculadas a ese sector, con la realidad rural como protagonista ante el peso de la densidad turística sobre la costa insular. En los casos de estudio, las áreas agrícolas y los espacios de recreación paisajística - costeros y/o rurales - componen el ámbito de oportunidad: su desarrollo ha influenciado el territorio e ilustran la relación entre población local y su modus vivendi.

El café que se planta en el Valle de Agaete y el vino de los viñedos de Alghero se beben en las terrazas que salpican sus costas, como un ejemplo de la sutil relación entre producción y cultura local y consumo turístico. Los intrínsecos valores paisajísticos y culturales de ambos territorios pueden componer por sí mismos una oferta, compresiva a la de playa, que permita redireccionar parte del flujo turístico hacia otras áreas, evitando replicar los casos de explotación urbana en el sur de Gran Canaria o el sobreuso de la costa en Cerdeña.

El análisis y reinterpretación de estos territorios, a través de la puesta en valor de los elementos que componen su identidad, permite esclarecer las reglas por las que se rige su relación con la comunidad local. $\mathrm{Si}$, como se ha expuesto previamente, el turismo supone una influencia exógena a esta relación, la oportunidad de fortalecer la cultura local, evitando su desvanecimiento o simulacro, puede suponer un mayor sentimiento de pertenencia al lugar y el aumento de la autoestima de la población local.

¿Puede ser reproducido este modelo en otros territorios costeros de similar escala?, ¿cuánto puede la cultura local resistir la influencia del turismo?, ¿dónde se encuentra el límite entre la protección del paisaje y el desarrollo urbano?, ¿cómo frenar el sutil pero continuo avance de los procesos de gentrificación turística? Cuestiones que aún necesitan tiempo para ser respondidas con seguridad, pero que permiten vislumbrar la existencia de casos de estudio comparables, donde usar este modelo de análisis para su planificación, cuya posterior herencia podría reflejar un sistema turista-residente completo en sí mismo, indivisible, en lugar de la continua lucha fría entre las necesidades, pretensiones y culturas de ambos. La clásica dicotomía entre paisaje natural y espacio urbano puede igualmente cambiar su perspectiva y ser concebidos como la relación inequívoca entre el territorio y la población que vive en él, suprimiendo la idea de "límite" y considerando los espacios de transición como la oportunidad de planificar una verdadera relación entre ambos espacios. Así, ante la premisa de redistribución de los flujos turísticos, se lograría rebajar la presión que éstos suponen sobre las áreas que tradicionalmente han tenido mayor reclamo, permitiendo que la población local pueda, finalmente, disfrutar el territorio que habita.

\section{Referencias}

Abarca, F. J., \& Campos, F. S. (2013). El paisaje desde el límite de lo urbano: una utopía necesaria y educadora. En Urban no 5: Paisajes críticos (63-78). Madrid: Editorial Munilla-Lería. 
Cáceres, E., \& Pescador, F. (2001). Paisaje y urbanización turística: el caso del sur de Gran Canaria. Urban $n$ o 6: Crecimientos suburbanos (15-34). Madrid: Tanais Ediciones.

Harvey, D. (2001). Spaces of capital. Towards a new critical geography. Edimburgo: Routledge.

Leyes de Ordenación del Territorio de Canarias y de Espacios Naturales de Canarias (2000). Texto refundido, aprobado por Decreto Legislativo 1/2000, de 8 de mayo de 2005.

Leyes de Ordenación del Territorio de Canarias y de Espacios Naturales de Canarias (2000). Texto refundido, aprobado por Decreto Legislativo 1/2000, de 8 de mayo de 2005.

Maccioco, G., \& Pittaluga, P. (2003). Immagini spaziali e progetto del territorio. Milán: Franco Angeli.

Macleod, D. V. L. (2004). Tourism, globalization and cultural change: an island community perspective. Bristol: Channel View Publications.

Manrique, C. (1988). Escrito en el fuego. Las Palmas de Gran Canaria: Edirca.

Mirallave Izquierdo, V., \& Pescador Monagas, F. (2005, 13-16 junio). Actas del Congreso Internacional "El espacio litoral: turismos insulares", Las Palmas de Gran Canaria, España, 2.

Onni, G. (2009). Forme turistiche e sostenibilità sociale. Alghero: Università degli Studi di Sassari.

Ostrom, E. (1990). Governing the commons. The evolution of institutions for collective action. Cambridge: Cambridge University Press.

Pittaluga, P. (2013). Landscape as a "Common": Collective Protection and Management. En S. Serreli, City Project and Public Space (179-195). Milán: Springer.

Sabaté, J., Frenchman, D., \& Shuster, J. M. (2004). Lugares con acontecimientos. Barcelona: Universidad Politécnica de Cataluña y Massachusetts Institute of Technology.

Sabaté, J. (2014). Turismo, paisaje y urbanismo; un diálogo necesario. En ACE no 25 (279-302).

Sauer, C. (1925). The morphology of landscape. En University of California publications in geography, vol. 2. California: University of California Press. 